\title{
Assessment of Restoration Potential in the Catchments of Pavana, Chaskaman and Dimbhe Dams in Northern Western Ghats
}

\author{
Dr. Swati Gole, Yogesh Pathak, Revati Gindi, Aditi Deodhar
}

Dr. Swati Gole is the Chairman and Co-founder, Ecological Society, Pune. She retired as Reader, Department of Geography, S. P. College, Pune. Email: swatipgole@gmail.com (Author for correspondence)

Yogesh Pathak is a management consultant and founder of EcoUniv, an environmental awareness initiative. He has served on the editorial team of the Journal of Ecological Society and is a visiting faculty in the Society's post-graduate diploma course.

Revati Gindi is an alumna of Ecological Society, Pune and is core member of Jeevitnadi Living River Foundation, Pune. She has done field botany and advanced field botany courses conducted by Agharkar Research Institute and Nisargsevak, Pune. Presently she is working as a consultant for ecological assessment and botanical projects.

Aditi Deodhar is an alumna of Ecological Society, Pune and is a core member of Jeevitnadi Living River Foundation, Pune. She is also the founder of Brown Leaf, a platform in Pune to eliminate burning of dry leaves which also encourages composting.

\begin{abstract}
Dam catchment regions in Western Ghats, a biodiversity hotspot, have special significance for its ecology and sustainable development. As a part of the Western Ghats mountain range, they host unique biodiversity that needs to be conserved. The study area viz. Pavana, Chaskaman and Dimbhe catchments are part of the Northern Western Ghats. These dams have been built on rivers that supply water to several large cities and to a large part of Maharashtra's agriculture in the Deccan Plateau. Conserving forest cover in these regions has a direct impact on water security. Considering the above factors the study of land use and vegetation was conducted in the catchments of Pavana, Chaskaman and Dimbhe. This study involved classification and identification of land use classes supported by ground truthing in the catchment areas.

For areas having degraded vegetation cover, the recommended approach was ecological restoration (Gole, 1990) (Gole, 2007). Based on this study we developed and tested a method to compare relative restoration potential and prioritization across multiple dam catchments. Restoration guidelines, both general and catchment-specific, were developed to guide an implementation program.
\end{abstract}

\section{Background and Scope of the Study}

In the years 2014-15, Global Forest Watch, under its Small Grants Program provided an opportunity to the Ecological Society, Pune, India to perform ecological surveys and assess the restoration potential in Northern Western Ghats at select dam catchments Pavana, Chaskaman and Dimbhe (Ecological Society, 2014).

These catchments are characterised by changes in land use after the construction of dams. The reasons for land use changes are as follows :

1. Ring-roads built around the dam catchment, resulting in housing development for urbanites

2. Displacement of villages on the valley floor due to the reservoir, resulting in re-settlement on upper slopes, shifting cultivation, etc. (Gole, 1985)

3. Modern and more intense agriculture

4. Quarrying, various small-scale industries, hotels and spa development, hill stations, townships, all followed by further road construction (Ecological Society, 2014).

The above activities have resulted in loss of forest cover and other forms of degradation of natural vegetation. Development, especially roads through the forest, has resulted in fragmentation of forest areas which are essential for the movement of the biodiversity.

Northern Western Ghats are the source region of 
major rivers like Krishna, Bhima, and Godavari. Hence water security of Maharashtra and other states like Karnataka, Andhra Pradesh and Telangana depends on the Western Ghats.

Due to the above reasons and their criticality, largescale conservation and ecological restoration of Northern Western Ghats has become absolutely necessary.

\section{Objectives}

This article documents the results of our study of natural vegetation cover, land use and ecological status of the catchment areas of three dams in the Western Ghats. The methodology employed was to classify the natural vegetation cover and assess the human use of land. The ecological status of the classified natural vegetation cover areas was evaluated to ascertain their restoration potential. The study area was the catchment areas of Pavana, Chaskaman and Dimbhe dams which lie on the eastern side of the Western Ghats, in Pune district.

The "Western Ghats" region is not only globally important for its biodiversity but locally it harbours very special biodiversity. However now it is developing fast and large areas within the region are being converted to second homes and farm houses. Modern poly-house agriculture is also practiced to a large extent. All these changes cause degradation of natural vegetation. As major rivers Krishna, Koyana, Bhima, etc. originate in Western Ghats, it is important to conserve their source region for water security. Restoration of the forests and other natural vegetation types holds an enormous potential for the revival of these rivers. Importance of restoration in the conservation of these areas is explained by Prof. Prakash Gole. In his book, 'The Restoration of Nature', he has highlighted why ecological restoration should receive a strategic importance :

"Can natural eco-systems ever be restored to their original form and functions? The answer appears to be a resounding 'no'. Yet 'Restoration', i.e. restoring ecosystems to viable forms and functions is undoubtedly important today."

"Restoration of degraded eco-systems to a viable form and substance should therefore, receive the highest priority in any plan of economic and social development. Unfortunately its importance and urgency are not recognized by anyone in India."

In this article, we also provide guidelines/recommendations that could be useful in restoration planning in the Northern Western Ghats. These recommendations can also be useful for researchers and restoration practitioners in the Western Ghats in general and dam catchments in particular. Finally, we aimed to develop a method for selecting restoration candidates by prioritizing and choosing from multiple such catchments.

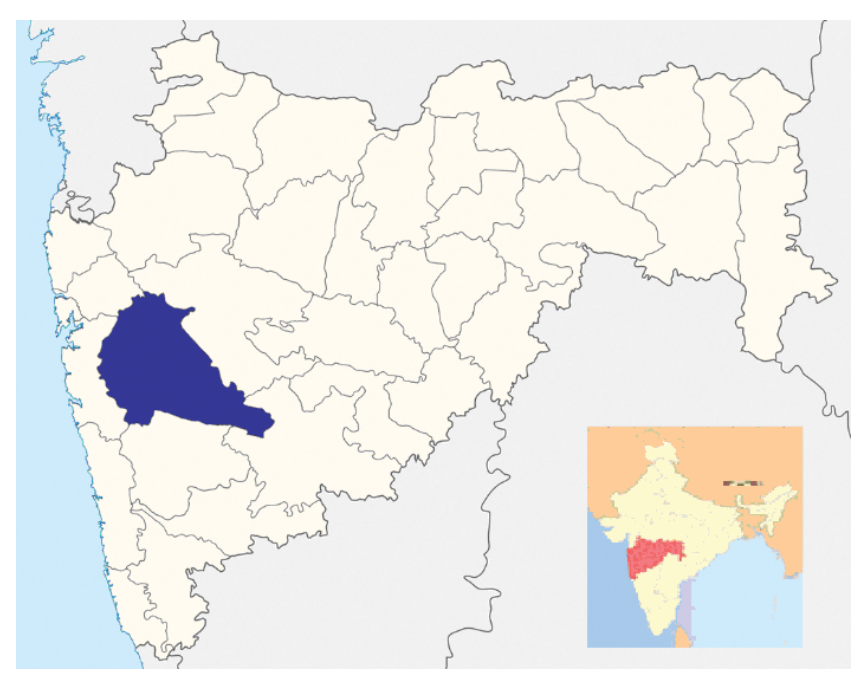

Figure 1: Location map of the state of Maharashtra and Pune district

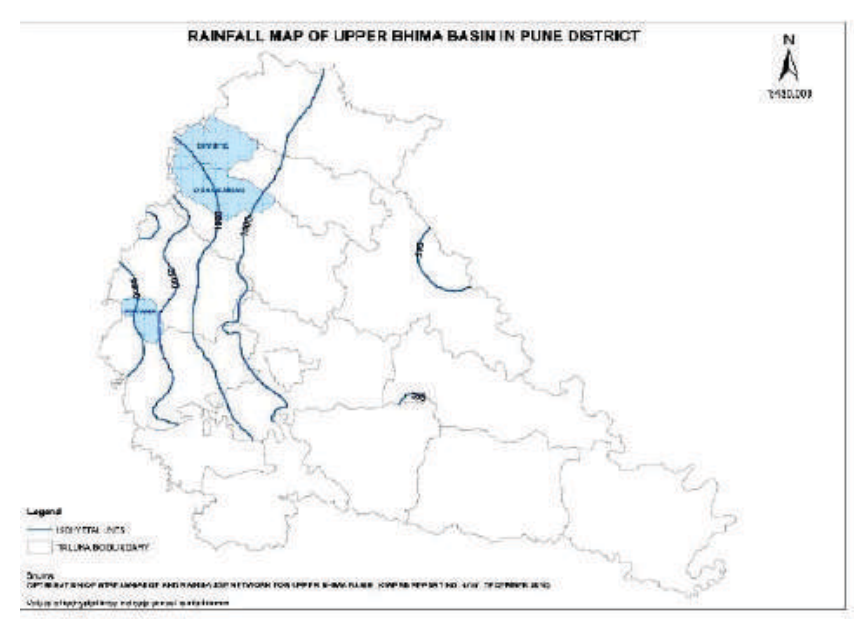

Figure 2 : Position of the three catchments.

Dimbhe Dam Catchment Tehsil Ambegaon, District Pune, Lat-Long: $19^{\circ} 6^{\prime} 38.08^{\prime \prime} \mathrm{N}, 73^{\circ} 43^{\prime} 28.68^{\prime \prime} \mathrm{E}$

Chaskaman Dam Catchment Tehsil Khed, District Pune, Lat-Long: $18^{\circ} 58^{\prime} 36.75^{\prime \prime} \mathrm{N}, 73^{\circ} 45^{\prime} 25.05^{\prime \prime} \mathrm{E}$

Pavana Dam Catchment Tehsil Maval, District Pune, Lat-Long: $18^{\circ} 40^{\prime} 14.44^{\prime \prime} \mathrm{N}, 73^{\circ} 29^{\prime} 28.99^{\prime \prime}$ E 
Table 1 : Key details of the catchments of Pavana, Chaskaman, and Dimbhe(WRIS, 2018)(CWPRS, 2010)

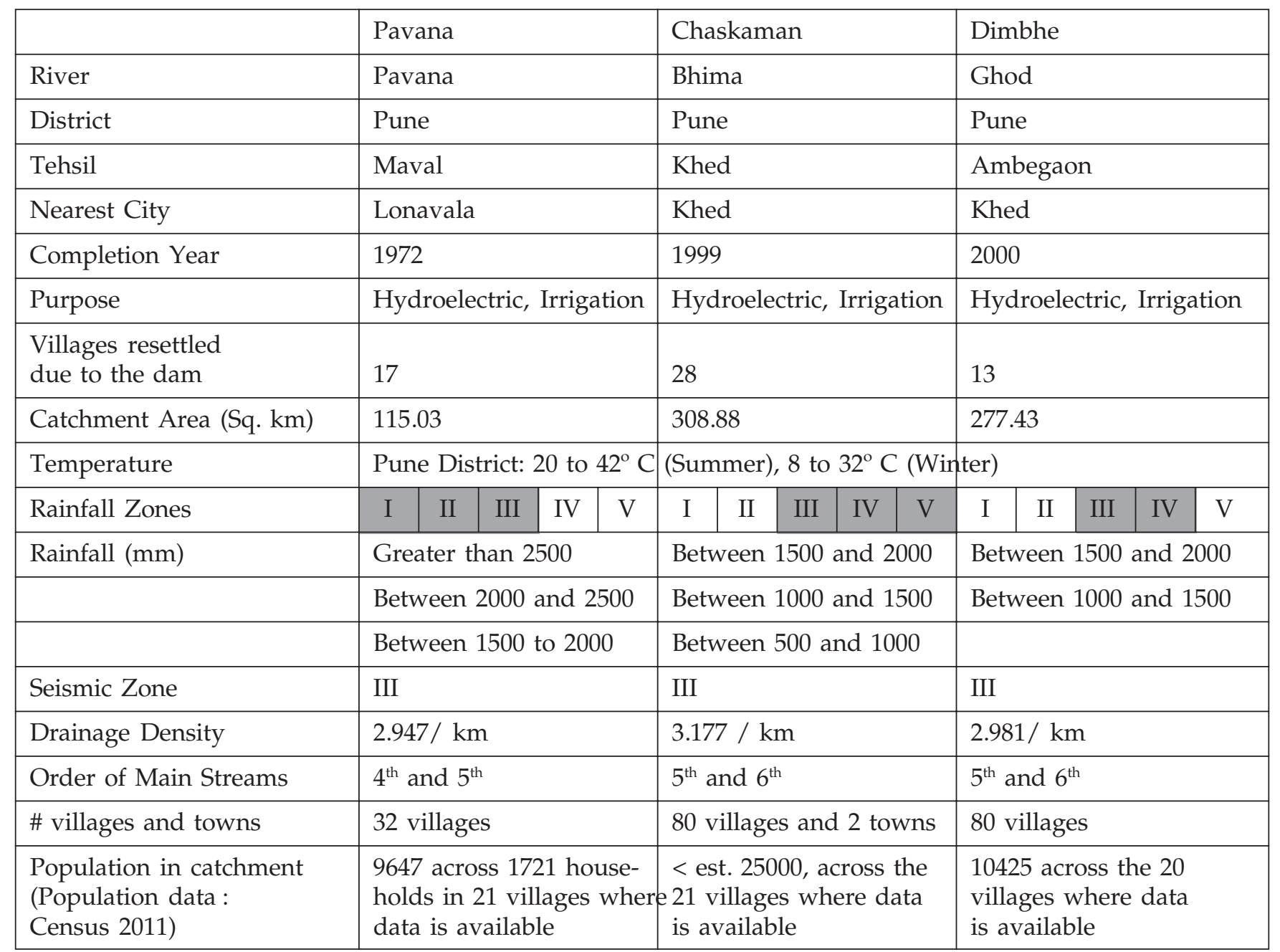

Note: The maps with rainfall zones, drainage map, and drainage density calculations for each catchment are given as part of online supplementary data.

\section{Study Process}

The study area i.e. the three catchments lie in the north and west of Pune district (Figure 1 and 2). Table 1 provides the key details for the three catchments.

For the selected three dam catchments, we performed the following process :

1. Satellite images were obtained and the dam catchment region was marked for study with the help of topographic sheets.

2. With the help of a GIS consultant and assigning vegetation class signatures, a mapping of the dam catchment by vegetation class and landusewas prepared (software: ArcGIS).
3. Field trips of the dam catchments were conducted to do ground truthing of vegetation classes.

4. Restoration potential was estimated and restoration guidelines are provided across dam catchments and specific to dam catchments.

5. Developed a method to prioritize and select when one has to choose from multiple such catchments.

As part of Step 4 above, we also developed a general-purpose restoration framework and detailed guidelines for restoration in the Western Ghats. This article mainly summarizes work done in Steps 1-3 and 5 with key results from step 4 . 


\section{Physical and social character of catchments}

\section{Pavana}

The physical character of the Pavana catchment shows steep slopes and narrow valleys near the crest line of the Sahyadri (Northern Western Ghats). The high drainage density indicates landscape made up of innumerable small sub-basins. The nature of the landscape is young, immature, and dissected.

The valley becomes broad in its middle and lower part. Basalt is the major underlying rock. The soil near the crest-line where heavy rainfall occurs is red while the soil in the valley is typical black cotton soil with silt- loam texture.

The Pavana dam catchment is located close to the cities of Pune, Lonavala and Mumbai. Its natural beauty and proximity to cities make it a favourite location for second homes of urbanites. The hills in the catchment are dotted with such farm-house development projects.

The forest patches are seen on the hill tops of the catchment however they are rapidly getting degraded due to residential construction. Junnar Division Working Plan of the Maharashtra Forest Department mentions that "Various detrimental agencies like fire, grazing, illicit cutting, encroachments, poaching etc. have a deleterious effect on the health and growth of the forest." (Gov. of Maharashtra, Forest Department, 2006)

In the valley, agriculture is predominant. Shifting cultivation, though on a small scale, is still practised on the hill slopes. Deviation from the traditional agriculture in the form of floriculture in poly-houses occupies a significant area.

This is not a densely populated area. Looking at the number of farm-houses, it is likely that this area has a floating population from the near-by cities of Lonavala, Pune and Mumbai.

\section{Chaskaman}

Steep slopes and high drainage density makes the North-western parts of Chaskaman catchment more rugged. Southern slopes of Bhimashankar form part of the Chaskaman catchment. Therefore nature of the landscape is young, immature, and dissected in the upper part of the valley. The middle part of the valley is relatively broad as significant Arala tributary with its sub-catchment joins the river Ghod, creating a terrain more complex.

In the Chaskaman dam catchment, traditional agriculture is observed. It does have human-induced stresses like clearing of mature forest for agriculture on privately-owned area. In-stream agriculture is practiced all over the catchment. Diverting the streams and creating terraces for cultivation alters the character of the stream and the drainage pattern. Modern development is also insignificant.

In spite of hilly and dissected character of the catchment, the number of human settlements is considerably high.

\section{Dimbhe}

The River Ghod originates on the Bhimashankar plateau. Here the plateau is extremely rugged as it is criss-crossed by several deep gorges of River Ghod and its tributaries. Thus physiography of the upper part of the Dimbhe catchment is very complex. (See Figure 3 for representative cross-section of Dimbhe catchment)

Physiography in the middle and the lower part of

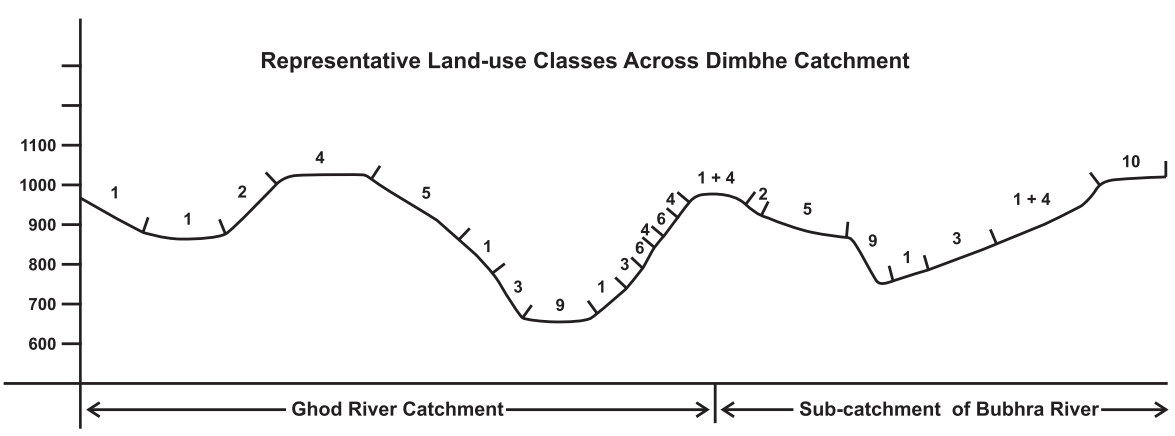

Figure 3 : Representative cross section of the Dimbhe catchment and the land use classes-

$Y$ axis: Altitude in meters; Scale: $1 \mathrm{~cm}=100$ meters, X axis: Ground distance in meters Scale: $1 \mathrm{~cm}=500$ meters, Index of land use/land classes: 1: Agriculture (Paddy), 2. Dense Shrubbery, 3. Plantation, 4. Scrub, 5. Mature Forest, 6. Cliff, 7. Reserved forest, 8. Agriculture - Shifting Cultivation patches, 9. River Channel, 10. Barren Land 
the catchment is very similar to the upper part i.e. rugged because spurs from the crest of the Western Ghats extends right up to the dam wall.

The Dimbhe catchment has predominantly tribal population in the hilly part. The local population is engaged in agriculture but is also dependent on the forest produce. The forest quality is good since it is adjoining the Bhimashankar wildlife sanctuary. In the valley, the main activity is subsistence agriculture.

It is observed that Bhimashankar shrine has become very popular for religious tourism. This has resulted in commercial and modern development in the catchment area.

\section{Methodology of the Study}

We adopted the methodology developed during the previous experience of forest analysis, vegetation assessment, and ecological restoration in the Ecological Society's research project which is described below-

\section{Reconnaissance Survey}

A preliminary survey of the catchment area was done torelate to the wider landscape. The main objectives were to understand

- the physiography of the catchment: whether its major part is hilly or moderately hilly or has larger proportion of plains, nature of the slopes, etc.

- general assessment of the vegetation cover and forest type

- presence of Devrai (Sacred Groves) which could be used as a reference ecosystem

- water resources and their status (whether they areperennial) etc.

- general density of village settlements

- area under agriculture, type of agriculture

- any other major human interventions.

\section{Acquisition of the Topo-sheets and Google Images}

Topographical-maps for the dam catchments were obtained from the Survey of India. The catchment area was identified by taking into account the water-divide. It also helped us in understanding the character of the slope, drainage and extent of forest.

We used the Google image of the catchments along with the topographical-maps. Marking of the water divide to demarcate the dam catchment was a combination of GIS work and close manual observations of topographical-maps. The catchment boundaries delineated on the topographical-maps were superimposed on the Google image.

\section{Mapping Process}

The project team worked with a GIS consulting team for the actual mapping of the defined vegetation and land-use classes on the Google image, using ArcGIS software. This identification was done based on the team's domain expertise, observations from the reconnaissance survey, and past projects done by Ecological Society. On an average, each image comprised of about 3000 such polygons.

Polygons where there was uncertain identification of vegetation were added to a "Query List". These polygons were confirmed by ground truthing in the actual field. The landscape is represented as an assemblage of polygons of various vegetation and land-use classes.

\section{Vegetation and Land Use Class Mapping}

The landscape is a mosaic ofnatural vegetation, plantation, agriculture and interventions like roads, quarries, other constructions etc. (Figure 4) Due to various human interventions, the landscape is further fragmented. This landscapewas then classified as Vegetation/Land Cover classes which refers to natural vegetation types like grassland, canopy forest etc. whereas the Land Use class refers to anthropogenic use like agriculture, roads, and settlements. The Vegetation and Land Use Classes used in this study are defined below. A detailed description, satellite image, and sample photo of each class is available in online supplementary data.

- Mature Forest: The vegetation class, 'Mature Forest' is defined as the area characterized by oldgrowth forest. It has a good percentage of old-growth trees and lianas.

- Dense Shrubbery: The vegetation class 'Dense Shrubbery' is defined as the area that is mostly

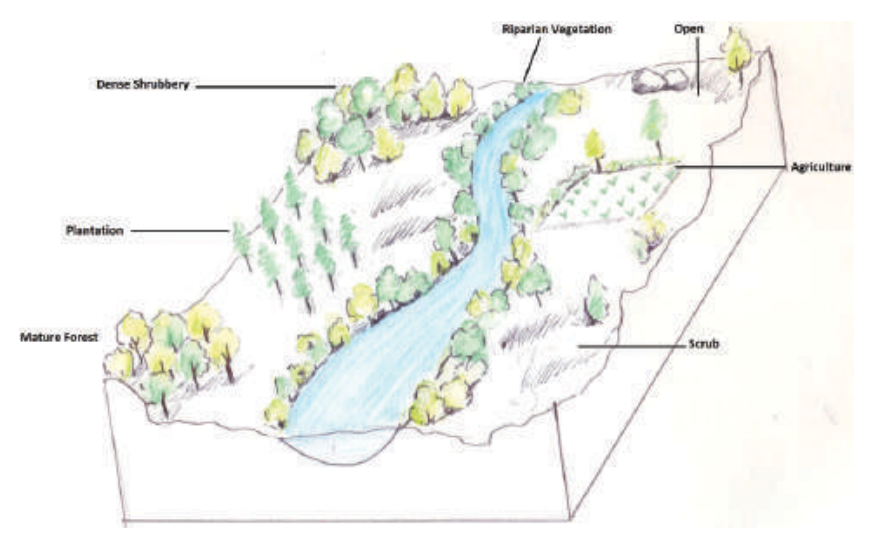

Figure 4 : Landscape as a mosaic of habitats 
covered with shrubs. It may have some tall trees or some sporadic open patches.

- Scrub: 'Scrub' is an area dominated with grassy under-growth, inter-mixed with shrubby clusters and dwarf canopy trees.

- Open Land : Open land with exposed rock, vertical cliffs and rocky outcrops are included in this vegetation class. In this study, we also included grasslands in Open Land.

- Karvi: Many of the highersteep slopes in the catchments are covered with Karvi (Strobilanthes callosus). These are pure stands without any other tree species. They cover very steep slopes with shallow substratum where survival of any other vegetation is difficult. Therefore Karvi becomes a distinct vegetation class.

- Riparian Habitat: A River and stream bank with riparian vegetation is covered in this vegetation class.

- Agriculture/ Horticulture: The dominant feature in this human land use class is agriculture and horticulture.

- In-stream Agriculture : This is an agricultural practice in the feeder stream of the river. It may often change the natural drainage flow of streams.

- Gaalper (Agriculture on reservoir bank): When the water level in the dam reservoir recedes, the land on the reservoir bank is exposed where agriculture is practiced.

- Plantation: Many times plantation is a monoculture and that too of non-native. It is manmade hence marked as a human land use class and not included under natural vegetation.

- Village Settlement : It is a village/hamlet with residential area. It may have housing built with traditional material and architecture or it may have modern housing.

- Modern Development: Any construction like greenhouse, farmhouse built using modern materials and architecture, windmills, industry, multistory buildings, business establishments like hotels, Resorts, were all categorized as Modern Development.

- Road: Only the tar/concrete roads were considered under this class.

- Quarry: Any quarry, whether working or abandoned, was considered under this class.

\section{Socio-economic conditions}

As a foundation for restoration planning, a detailed socio-economic analysis of the region is essential i.e. the people residing in the area, their resource needs, the local economy and its integration with the national economy, and fulfilment of their needs through local natural resources. Secondary data collected on socioeconomic conditions is being analyzed separately and not covered in this article.

\section{Management information from government agencies}

A major stakeholder is the government, i.e. departments like Forest Department, Department of Social Forestry and Water Resources Department (formerly, the irrigation department). To find out their land use and utilization and management of natural resources in the catchment, the project team visited the respective departments and got an understanding of their policies and working.

Forest resources of these catchments are managed by the Forest Department. Its role is to protect, conserve and enhance the forest resource. Pavana and Dimbhe contain a significant area under forest department's ownership ( $21 \%$ and $\sim 16 \%$ respectively per our estimates), while Chaskaman has relatively less area under forest department (estimated to be around 5-6\%).

Forests are cut mainly for timber and fire-wood by local people. The department of Social Forestry came into existence to help locals and fulfil their needs by energy plantation on their own land, thereby reducing stress on the government-owned forest. This Department does not own any land by itself. Methods of operation of Social Forestry Department are summarized in online supplementary data.

The Water Resource Department is another major stakeholder as water resources from the catchment area are managed by this department by storing water behind the dam and redistributing it through canals.

To better understand the government stakeholders, the following were studied:

- 10-year working plans by the Forest Department for Junnar division (2004-05 to 2013-14) and Pune division (2012-13 to 2021-22). (Gov. of Maharashtra, Forest Department, 2006), (Gov. of Maharashtra, Forest Department, 2011)

- Various schemes by the department of Social Forestry

- The detailed draft plan for the Upper Bhima basin by the Water Resources Department (Gov. of Maharashtra, Water Resources Department, (n.d.).)

We tried to relate the secondary data from the Forest Department and Water Resource Department to understand resource distribution among local communities and people outside the catchment. 


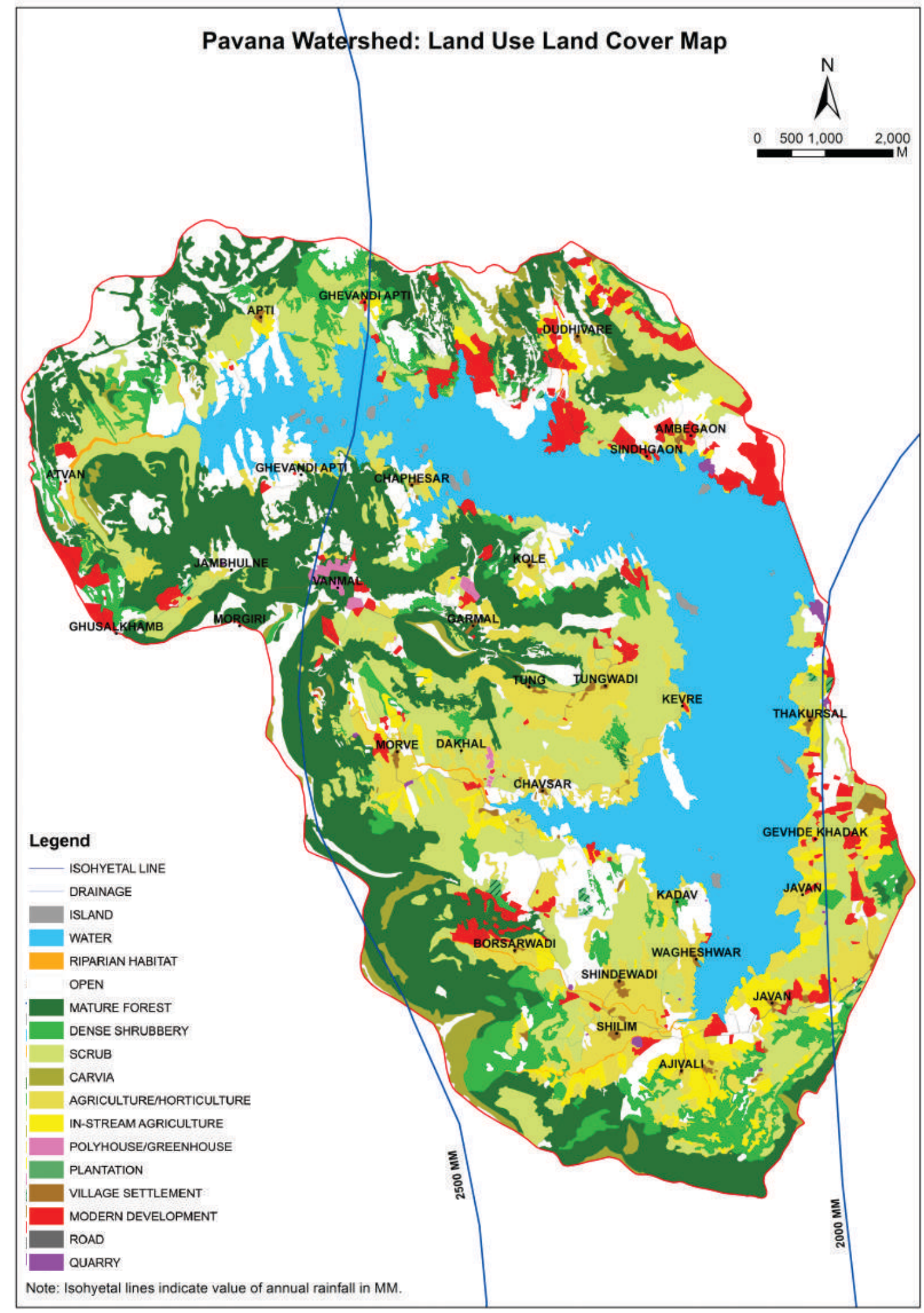

Figure 5: Pavana Catchment: Vegetation and Land Use Map 


\section{Results}

The analysis and interpretation of the Land-use classes in each catchment is given below.

\section{Pavana: Vegetation classes and Composition}

Figure 5 shows the vegetation and land use map of Pavana catchment. Table 2 shows area statement by vegetation and landuse and Table 3 shows vegetation composition.

\section{Pavana: Observations and Comments}

- The western part of the catchment, near crest-line, has high rainfall $(2500 \mathrm{~mm})$. Semi-evergreen forest is observed in this area having composition of Memecylon-Actinodaphane-Syzygium associated with Olea dioica, Atlantia racemosa, Glochidion ellpticum, etc.

- Moist deciduous type of forest was observed in the zone with the rainfall between $1500 \mathrm{~mm}$ and 2500 mm which includes Terminalia sps.-Bombax ceiba, Ficus racemosa, associated with Meyna laxiflora, Albizzia chinensis, etc.

- Mature Forest is mainly observed at the mountain tops, base of vertical cliffs, slopes and ravines, near the crest-line.

- In zone III, with rainfall less than $1500 \mathrm{~mm}$, dry deciduous forest type was observed with Acacia sps., Bombax ceiba, Boswellia serrata, Cassine glauca, etc.

- A Sacred Grove is present at the base of Fort Tung $\left(18^{\circ} 39.862^{\prime \prime} \mathrm{N}, 73^{\circ} 27.447^{\prime \prime} \mathrm{E}\right)$ and is named after the goddess Waghjai. Its area is 0.34 acres. It is surrounded by agricultural land. Dense patch of unique vegetation of Pandanus sp. is an indicator of high ground water level which was validated by the flowing perennial well. Old growth trees like Caryota urens, Syzygium cuminii, Mangifera indica, Olea dioica, Ficus racemosa, Atlantia racemosa associated with climbers like Elaeagnus conferta, Dalbergia horrida, Tylophora dalzelii, Jasminum malabaricum are found in this sacred grove.

- The Pavana catchment also consists of a few more sacred groves. The Ajivali sacred grove is a known example for its commercial management by local community.

- The Pavana catchment has lot of modern development, having resorts, farm houses and spas. Road construction through thick forest near village Dudhivare pass has fragmented the forest, and resulted in soil erosion. (Figure 6)

- Dwarf canopy forests with composition of
Memecylon-Syzygium-Actinodaphane associated with Canthium dicoccum, Careya arborea, Macaranga peltata, etc. which is a typical montane forest composition near the crest line was also observed in Pavana catchment.

- Dense Shrubbery was observed with intermittent trees on gradual slopes found in all rainfall zones. As the rainfall zone changes, tree species in the dense shrubbery also changes. E.g. Memecylon, Actinodaphane in high rainfall zone area and Terminalia, Bombax in low and medium rainfall zone.

- At places Karvi patches dotted with trees like Olea dioica, Memecylon umbellatum near crest-line were observed on the steep slopes.

- Abundant shifting cultivation patches with good shrubby growth were observed on the higher slopes.

- In dwarf canopy forest, the composition is more or less similar to dense shrubbery with increased tree density.

- Dense shrubbery patches are termed as regenerating patches because vegetation structure is in regenerating state due to presence of root stocks. These areas have a good potential for restoration as these are moderately degraded areas compared to scrublands

- Observed intermittent coppiced trees of Dillenia pentagyna, Terminalia elliptica, Syzygium cuminii, Carrisa congesta in land patches used for Rab (It is an age-old practice in which farmers burn the piece of land before cultivation). Farmers also cut standing trees on the plot where they want to cultivate. These patches indicate earlier canopy forest.

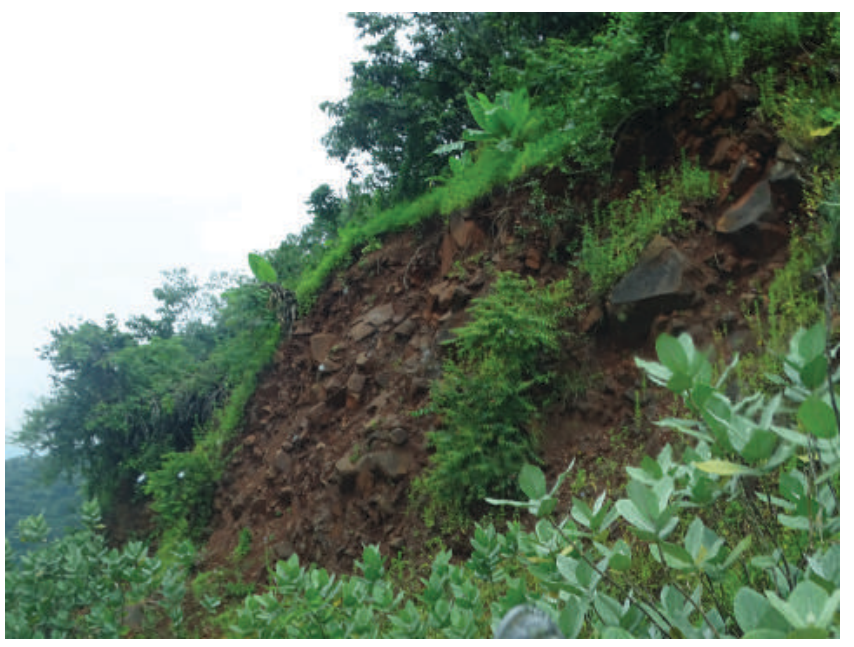

Figure 6: Example of soil erosion 
Table 2 : Pavana Catchment : Area Statement as per Vegetation and Land Use

\begin{tabular}{|l|l|l|}
\hline Vegetation and Land Use Class & $\begin{array}{l}\text { Area under the } \\
\text { each Class } \mathbf{( s q .} \text { km) }\end{array}$ & $\begin{array}{l}\text { Percentage Area w.r.t. } \\
\text { Total Catchment Area (\%) }\end{array}$ \\
\hline Mature Forest & 25.337 & 22.02 \\
\hline Dense Shrubbery & 7.000 & 6.08 \\
\hline Scrub & 18.807 & 16.34 \\
\hline Open Land & 17.634 & 15.33 \\
\hline Karvi & 2.096 & 1.82 \\
\hline Riparian Habitat & 0.329 & 0.28 \\
\hline Islands & 0.282 & 0.24 \\
\hline Waterbody & 23.993 & 20.85 \\
\hline Agriculture/ Horticulture & 9.794 & 8.51 \\
\hline In-Stream Agriculture & 3.602 & 3.13 \\
\hline Plantation & 0.182 & 0.15 \\
\hline Village Settlement & 0.551 & 0.47 \\
\hline Modern Development & 4.468 & 4.1 \\
\hline Road & 0.556 & 0.48 \\
\hline Quarry & 0.145 & 0.12 \\
\hline Total Area & $\mathbf{1 1 5 . 0 3}$ & $\mathbf{1 0 0}$ \\
\hline
\end{tabular}

- Scrub vegetation includes woody, hard, thorny vegetation along with weeds like Lantana camara and indicates significant degradation. This class was observed throughout the catchment especially near settlements and lower slopes near valley floor and near the main water-body.

- Areas recently created for shifting cultivation are very similar to scrub areas.

- Scrubland supports pioneer species of flora and fauna i.e. habitat-generalist species. Excessive cutting of trees for fuel wood, grazing, and fire may lead these areas towards more and more degradation. Protection, management and restoration is required to improve its ecological value.

- Open area is observed at places like mountain tops, vertical cliffs, exposed rocky area, rocky plateaus and is scattered throughout the catchment.

- Land use in the open areas is related to soil cover. Open areas with good soil cover are used for cultivation by the locals while open areas with shallow soil are used for grazing. At places we observed quarries indicating degradation of land- scape.

- Open land bordering the main water body is barren and does not support any vegetation because these areas are submerged for a long period of time during the year.

- Vertical cliffs support lithophytic vegetation with high desiccation tolerance to withstand harsh conditions.

- Part of the Open vegetation class, Rocky Outcrops are a special habitat in the Northern Western Ghats. They support habitat specific flora and fauna with many endemic, rare and endangered species and provide refuge to small as well as medium animals in harsh weather. The rocky outcrops have high biological value. However, they are treated as wasteland due to lack of knowledge and poor scientific understanding. Many of them are being made open for development, which is a serious threat.

- Practice of Gaalper agriculture is common when water recedes during non-rainy season.

- Steep scree-covered slopes, often just below the 
Table 3 : Pavana Catchment : Vegetation Classes and Composition

\begin{tabular}{|c|c|}
\hline $\begin{array}{l}\text { Vegetation } \\
\text { class }\end{array}$ & Species Composition \\
\hline \multirow[t]{3}{*}{$\begin{array}{l}\text { Mature } \\
\text { forest }\end{array}$} & $\begin{array}{l}\text { Semi evergreen : Memecylon-Actinodaphane-Syzygium associated with Olea dioica, } \\
\text { Ficus racemosa, Atlantia racemosa, Terminalia chebula, etc. with understorey of trees like } \\
\text { Meyna laxiflora, Macaranga peltata, Callicarpa tomentosa, Glochidion ellipticum and } \\
\text { Mallotus philippensis, etc. } \\
\text { The ground flora includes Asystasia dalzellina, Desmodium triquetrum, etc. }\end{array}$ \\
\hline & $\begin{array}{l}\text { Moist deciduous : Terminalia tomentosa- Bombax ceiba - Ficus racemosa associated with } \\
\text { trees like Bridelia retusa, Careya arborea, Albizzia chinensis, Wrightia tinctoria, Garuga pinnata, } \\
\text { Emblica officinalis, Grewia tilifolia, Meyna laxiflora, Kydia calycina, Dillenia pentagyna and } \\
\text { climbers like Elaeagnus conferta, Jasminum malabaricum, Stephania japonica, Cocculus hirsutus, } \\
\text { Dalbergia horrida, etc. }\end{array}$ \\
\hline & $\begin{array}{l}\text { Deciduous forest: Terminalia bellirica, Acacia chundra, Acacia ferruginea, } \\
\text { Lannea coromandelica, Bombax ceiba, Boswellia serrata, Cassine gluca, Bauhinia racemosa, } \\
\text { Woodfordia fruiticosa, Clerodendrum serratum, Asparagus racemosus, etc. }\end{array}$ \\
\hline $\begin{array}{l}\text { Dense } \\
\text { shrubbery }\end{array}$ & $\begin{array}{l}\text { Carrissa congesta, Gnidia gluca, Lantana camara, Woodfordia fruticosa, Casearia graveolens, } \\
\text { Pavetta crassicaulis, Holarrhena pubescens, Leea indica, Pogostemon benghalensis, Calotropis } \\
\text { gigantea, Strobilanthes callosa with intermittent trees like Terminalia elliptica, Bridelia retusa, } \\
\text { Flacourtia indica, Bombax ceiba, Syzygium cuminii, Ficus hispida, Emblica officinalis, } \\
\text { Wrightia tinctoria, Memecylon umbellatum, etc. } \\
\text { Dwarf canopy forests with composition of Memecylon-Syzygium-Actinodaphne associated } \\
\text { with Canthium dicoccum, Careya arborea, Macaranga peltata, Xantolis tomentosa, etc. }\end{array}$ \\
\hline Scrub & $\begin{array}{l}\text { Themeda quadrivalis, Apluda mutica, Heteropogon contortus intermixed with clusters of Lantana } \\
\text { camara, Carrisa congesta, Woodfordia fruticosa, Gnidia gluca, Calotropis gigantea, Euphorbia } \\
\text { nerifolia. } \\
\text { The clusters also included dwarf trees like Bombax ceiba, Meyna laxifora, Terminalia elliptica, } \\
\text { Syzygium cuminii, Grewia tillifolia }\end{array}$ \\
\hline Open area & $\begin{array}{l}\text { Typical rocky plateaus during monsoon become green with herbaceous vegetation; } \\
\text { species like Utricularia, Eirocaulon, Smithia, Impatiens, Crotalaria, Indigofera, Swertia minor, } \\
\text { Sopubiadelphinifolia decorate these rocky plateaus. } \\
\text { Orchids like Habenaria grandifloriformis observed associated in grassy patches associated } \\
\text { with Heteropogon contortus, Themeda, Apluda, Andropogon and shrubby clusters of } \\
\text { Carrisa congesta, Gnidia gluaca, Meyna laxiflora, etc. } \\
\text { Vertical cliffs supports typical vegetation of species like Ensete superbum (Wild Banana), } \\
\text { Ficus arnottiana, Hymeodyction obovatum, Tripogon lisboe, Euphorbia ligularia, etc. }\end{array}$ \\
\hline Karvi & $\begin{array}{l}\text { Strobilanthes callosa, Strobilanthes reticulata are associated with climbers like Dioscorea spp, } \\
\text { Tylophora dalzelii, etc. }\end{array}$ \\
\hline Riparian & $\begin{array}{l}\text { Ficus racemosa, Syzygium cumini, Pongamia pinnata, Syzygium zeylanicum, Homonoia riparia } \\
\text { along with other terrestrial species like Bombax ceiba, Lannea coromandellica, Xantolis tomentosa, } \\
\text { Cyperaceae members and some grasses like Saccharum spontaneaum, herbs and shrubs like } \\
\text { Ludwigia octovalvis, Phyllanthus reticulatus, etc. }\end{array}$ \\
\hline Plantation & $\begin{array}{l}\text { Gliricidia sepium, Eucalyptus globules, Leucaena latisiliqua, Casuarina equisetifolia, } \\
\text { Acacia auriculiformis, Cocos nucifera }\end{array}$ \\
\hline
\end{tabular}


cliffs, support Karvi vegetation. On such steep slopes, usually nothing other than Karvi grows.

- Karvi patches were also observed on steep and moderate slopes of the historic forts Tung, Tikona and Lohagad. A few patches were observed along the road and near crest-line. e.g. Lions Point at Lonavala.

- Though the area under Karvi is not significant, it needs to be protected since it plays a major role in preventing soil erosion on the slopes and provides a habitat for wild fauna. This function is especially important in dam catchments, since soil erosion causes siltation of the dam reservoirs.

- Karvi stems are used by local people for building houses and agricultural and also in 'Rab' practices. Thus, managing its extraction in a sustainable way is recommended and this is a challenge in management in the catchment.

- The riparian species composition is special because these species tolerate water level changes. The species mentioned in composition are found in most riparian habitats in Western Ghats and also found in the catchments in this study.

- Riparian vegetation is precious and must be maintained and protected. Its ecological value is very high for reasons below:

- It creates additional habitat diversity and adds to the mosaic of habitats in the landscape.

- It acts as an interface between the river/ stream and land.

- It filters the sediments and thus reduces the sediment load in the river. It can control rate of siltation in dam reservoirs.

- Riparian areas with good vegetation serve as corridors for movements of materials and organism and work as breeding grounds of many faunal species.

- It also helps to maintain micro climate and in reducing bank erosion.

- This habitat needs to be protected, restored and enhanced with proper methods.

- Considering the entire catchment, the area under plantation is not significant in percentage. It is especially found near modern development and open areas. Species like Subabhul and Gliricidia have traditionally been preferred in plantations in $\mathrm{W}$. Ghats in spite of being exotic. Indigenous species are recommended for plantation for ecological integrity.

- Area under modern development is $4.1 \%$ which includes farm-houses (individual plots and schemes), polyhouses, etc. This area, due to its proximity to the cities like Pune, Mumbai and Lonavala is a favourite place for a 'second home' for the city-dwellers. Another activity of modern agriculture is floriculture in polyhouses. The spread of polyhouses is significant. (Figure 7)

- We saw some abandoned stone quarries in the catchment. e.g. near Thakursai village adjacent to the dam wall. In the quarries, there is no substratum, but completely exposed rock. Such areas are difficult to restore ecologically as there is no soil left. However such areas, if protected and restored, will provide refuge to a variety of biodiversity. (Figure 8) (Bradshaw et. al., 1980)

\section{Chaskaman: Vegetation Classes and Composition}

Figure 9 shows the vegetation and land use map of Chaskaman catchment. Table 4 shows area statement by vegetation and landuse and Table 5 shows vegetation composition.

\section{Chaskaman: Observations and Comments}

- Natural vegetation classes comprise of $60.68 \%$ of the total catchment area.

- The area under open land and scrub land together is above $35 \%$ indicating long-term degradation.

- Part of the Bhimashankar wildlife sanctuary is in this catchment. Mature forest is observed only near Bhimashankar, Nigdale and Bhorgiri area.

- Evergreen forest was observed at Guptbhima and near the Forest Department's rest-house area of Bhimashankar Wildlife Sanctuary. Protection and less human disturbance will ensure conservation of this good forest cover.

- As rainfall decreases from the west to the east, vegetation composition accordingly changes from evergreen species to semi evergreen and moist deciduous.

- The Bhimashankar Wildlife Sanctuary is protected for the Malabar Giant Squirrel (Shekaru), i.e. Ratufa indica which is a keystone species and endemic to the Western Ghats.

- On the way to Taleghar from Bhorgiri, observed newly created agricultural plots by clearing of good vegetation cover on Forest Department land.

- All the mature forest is mostly found in protected area, near crest-line.

- There are many open areas adjacent to the mature forest patches. On inquiry, we found out that they are privately owned. Owners may purposely clear forest on their land to assert their right on that land and to practice agriculture there. Such instances are highly detrimental to natural forests. 


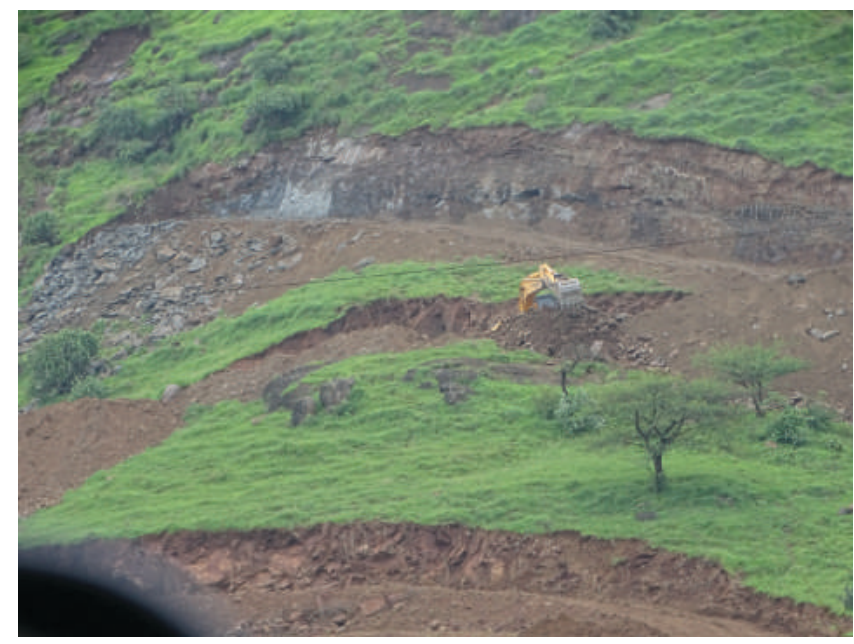

Figure 7 : Road building for modern development

- The surrounding area of Kalmodi has tribal settlements. This area has rolling hill slopes with flat mountain tops. This area should support moist deciduous forest. But most of the area is highly degraded and barren. This might be due to shifting cultivation, exploitation of forest for timber, firewood and grazing etc.

- Scrub areas in Chaskaman catchment is mostly observed near dam wall and near settlements.

- There is no specific composition of species in open area, but observed the following:

- Euphorbia sp. (Nivdung) appearing in open patches, associated with woody and hardy vegetationindicating xerophitic condition.

- Rocky outcrops : Many of the open land habitat are rocky outcrops. They have specific vegetation during monsoon.

- At places there is dominant grassy vegetation dotted with clusters of stunted trees, shrubs, herbs and climbers.

- This study observed cattle tracks on the hill slopes. The extent of the cattle tracks indicated intensive grazing. The rainfall in this area indicates it should have a good forest cover but this is not seen, leading to the conclusion that the area is overgrazed.

- Karvi patches were observed at the end of the catchment near Bhorgiri.

- High altitude, high rainfall, steep slopes and rubble strata support Karvi vegetation.

- Though small in percentage, Karvi is very important in reducing soil erosion on the slopes. This function is especially important in dam catchments, since soil erosion causes siltation of the dam reser-

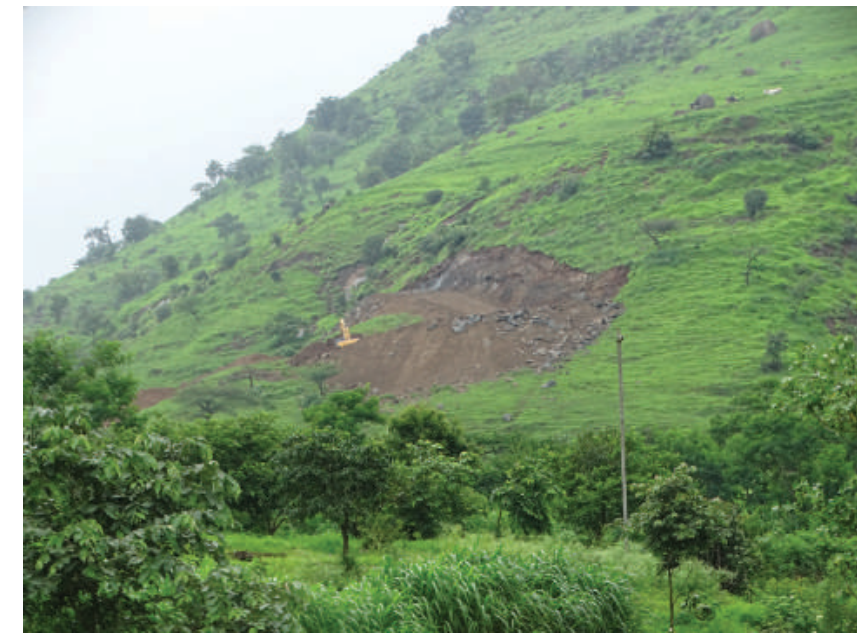

Figure 8: Stone quarries

voirs.

- Teak (Tectona grandis) is the most widely planted species in the catchment.

- From the Dam wall, we observed Teak plantation till the village Mandoshi, which formed the dominant floral feature in the landscape. Such plantation is done on forest department land as well as on private lands through Social Forestry initiative. Hence, natural vegetation could be observed from Mandoshi onwards in the western part of the catchment.

- Nilgiri plantation was also observed near Dehane village.

- Modern development has not yet emerged as a significant threat to the landscape, but this may change in future. At a few places, we saw roads being constructed right on the hill for proposed projects. (Figure 10)

\section{Dimbhe: Vegetation Classes and Composition}

Figure 11 shows the vegetation and land use map of Dimbhe catchment. Table 6 shows areastatement by vegetation and landuse and Table 7 shows vegetation composition.

\section{Dimbhe: Observations and comments}

- Natural vegetation classes comprises of $64.96 \%$ of the total catchment area.

- Mature forest is higher as compared to Chaskaman in Dimbhe

- Open area is maximum $(19.39 \%)$ of all the vegetation classes indicating high level of degradation.

- The area occupied by plantation is significantly low. 


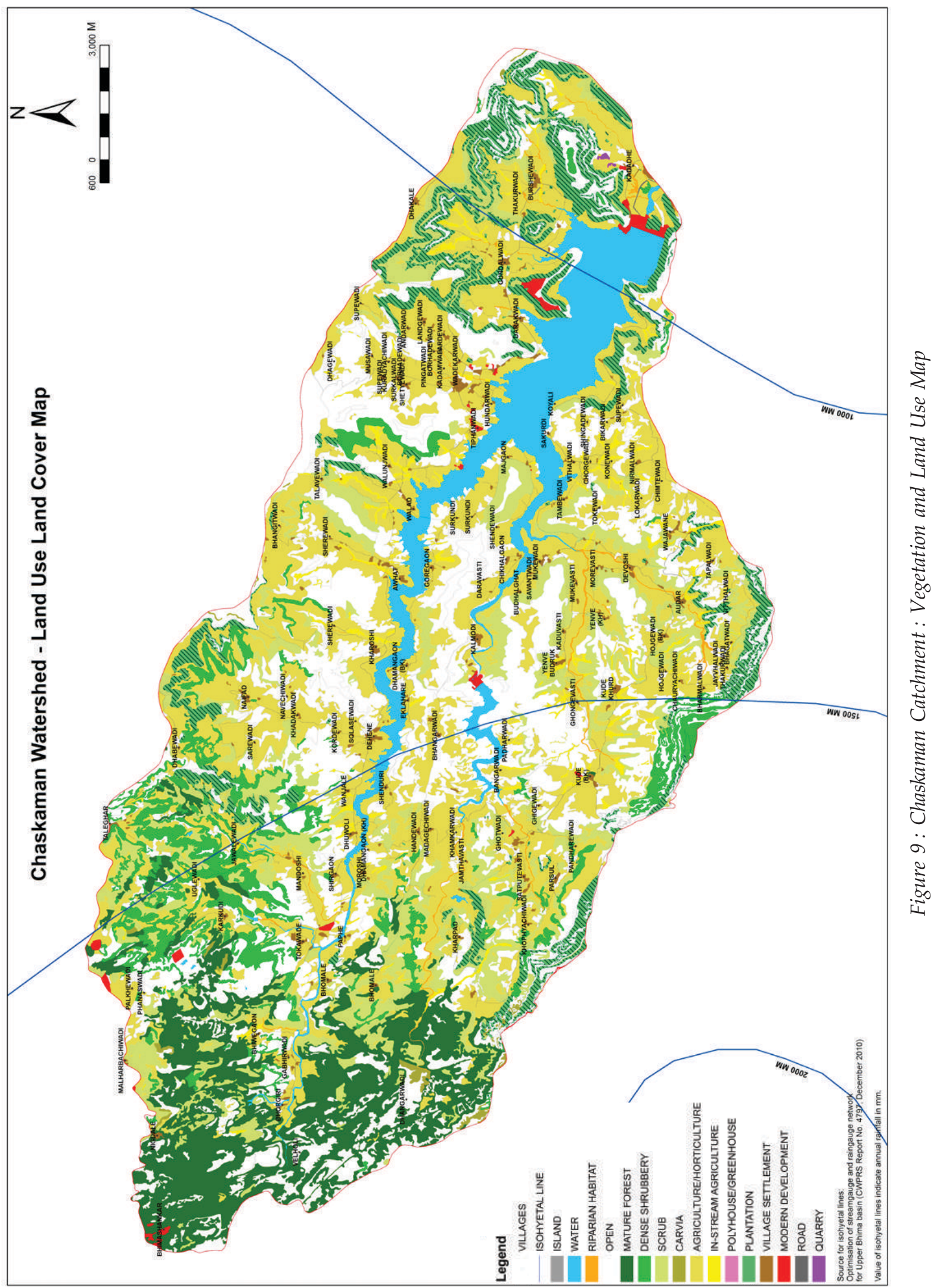


Table 4 : Chaskaman Catchment : Area Statement as per Vegetation and Land Use

\begin{tabular}{|l|l|l|}
\hline Vegetation and Land Use Class & Area under each Class $\mathbf{( s q} . \mathbf{~ k m})$ & $\begin{array}{l}\text { Percentage Area w.r.t. } \\
\text { Total Catchment Area (\%) }\end{array}$ \\
\hline Mature Forest & 29.947 & 9.69 \\
\hline Dense Shrubbery & 17.716 & 5.76 \\
\hline Scrub & 37.300 & 12.07 \\
\hline Open & 81.083 & 26.25 \\
\hline Karvi & 0.820 & 0.265 \\
\hline Riparian Habitat & 1.149 & 0.37 \\
\hline Islands & 0.000 & 0 \\
\hline Waterbody & 19.591 & 6.34 \\
\hline Agriculture/ Horticulture & 91.132 & 29.50 \\
\hline In-Stream Agriculture & 5.276 & 1.70 \\
\hline Plantation & 19.407 & 6.28 \\
\hline Village Settlement & 2.611 & 0.84 \\
\hline Modern Development & 1.178 & 0.38 \\
\hline Road & 1.621 & 0.52 \\
\hline Quarry & 0.050 & 0.016 \\
\hline Total & $\mathbf{3 0 8 . 8 8} \mathbf{s q . ~ k m}$ & $\mathbf{1 0 0}$ \\
\hline
\end{tabular}

- The Dimbhe catchment receives rainfall of less than $2000 \mathrm{~mm}$, hence it is unable to support species of evergreen forest. In the Western part of the catchment, semi-evergreen forest is present. The second important forest type seen here is the moist deciduous forest.

- The Sacred grove (Devarai) near village Phalode is devoted to the deity named Marideo. It has old growth trees like Ficus amplissima (Piparani), Terminalia chebula (Hirada) associated with Syzygium cuminii (Jambhul), Atalantia racemosa (Makadlimbu), Mangifera indica (Amba), Casearia graveolens (Bokhada), Actinodaphane angustifolia (Pisa), etc.

The Devrai is located near the main road and surrounded by agricultural land with a few settlements. Therefore, it has become isolated and lost connection with other forest patches. Prominent edge-effect could be observed with weeds and hardy species like Lantana camara (Tantani), Crotalaria pallida (Khulkhula).

- The Ahupe sacred grove is fragmented by road. It has many old growth trees and lianas. It is an ideal habitat for Ratufa Indica, the Indian giant squirrel which is a key-stone species and endemic to the Western Ghats.

- Community conserved Hirada trees are present in Phalode and in many other villages in the catchment area. Collection and sale of Hirada fruits is one of the income sources for the locals in this catchment.

- Mature forest was also observed at the end of the west side of the catchment which includes area of Kondhwal and Ahupe located near the crest-line.

- Good forest patches were seen near $1^{\text {st }}$ order stream niches which are almost inaccessible for the humans and have higher availability of moisture.

- The composition of dense shrubbery in this catchment is more diverse, with relatively larger number of species. Please see vegetation composition in tabular format given in Table 7.

- The opportunity to improve the status of dense shrubbery to mature forest by restoration is significant. 
Table 5 : Chaskaman Catchment : Vegetation Classes and Composition

\begin{tabular}{|c|c|}
\hline & $\begin{array}{l}\text { Species Composition } \\
\text { Evergreen : Memecylon-Garcinia-Dimorphocalyx-Litsea are associated with } \\
\text { Mallotus stenanthus, Mallotus aureopunctatus, Knema attenuata, Drypetes venusta, } \\
\text { Mangifera indica, Syzyzium cumini, Ficus nervosa, Garcinia spp. }\end{array}$ \\
\hline & $\begin{array}{l}\text { Semi-evergreen : Memecylon-Actinodaphne-Olea community is associated with } \\
\text { Mangifera indica, Heterophragma quadriloculare, Diospyros silvatica, Atalantia racemosa, } \\
\text { Mallotus phillipensis, Murraya koenigi, Bridelia retusa, Xantolis tomentosa. Ground flora } \\
\text { includes shrubs like Ixora brachiata, Gnidia gluca, Pavetta indica, etc. }\end{array}$ \\
\hline & $\begin{array}{l}\text { Moist Deciduous forest: Terminalia spp.-Dalbergia spp.-Bombax ceiba, Erythrina stricta, } \\
\text { Ficus racemosa, Lagerstromia parviflora, Zanthoxylum rhetsa, Grewia tiliifolia, Careya arborea, } \\
\text { Meyna laxiflora are asociated with climbers like Dioscorea bulbifera, Paracalyx scariosus, } \\
\text { Teramnus labialis, Tylophora dalzeli, Smilax ovalifolia. }\end{array}$ \\
\hline Dense shrubbery & $\begin{array}{l}\text { Strobilanthes callosa, Woodfordia fruticosa, Carrisa congesta, Pavetta sp, Gnidia glauca, } \\
\text { Thespecia lampas, Grewia serrulata, Casearia graveolens, Holarrhena pubescens, Meyna laxiflora, } \\
\text { Catunaregum spinosa and trees like Terminalia elliptica, Bridelia retusa, Flacourtia latifolia, } \\
\text { Bombax ceiba, Syzygium cuminii, Ficus hispida, Emblica officinalis, Wrightia tinctoria, Acacia } \\
\text { feruginea, Tectona grandis }\end{array}$ \\
\hline Scrub & $\begin{array}{l}\text { Acacia nilotica, Azadiracta indica, etc. associated with shrubs like Fluggea leucopyrus, } \\
\text { Calotropis gigantea, Lantana camara, Euphorbia sp., Woodfordia fruticosa, Gymnosporia sp., etc. }\end{array}$ \\
\hline Open area & $\begin{array}{l}\text { There is no specific composition of species but we observed the following: } \\
\text { At places observed Euphorbia spp. associated with Artemisia nilagirica indicating } \\
\text { xerophytic condition. } \\
\text { Many of the open land habitat are rocky outcrops. They have specific vegetation during } \\
\text { monsoon and following are some of the species seen: } \\
\text { Eriocaulon-Utricularia-Smithia-Senecio associated with Nanothamnus sericeous, Cythocline } \\
\text { lutea, Cythocline purpurea, Hygrophilla serpyllum, Smithia purpurea, grasses, sedges } \\
\text { associated with shrubby clusters of Gnidia glauca, Catunaregum spinosa, Crotalaria retusa } \\
\text { and Carissa spinarum, etc. }\end{array}$ \\
\hline Karvi & Strobilanthes callosa associated with climbers like Dioscorea spp., Tylophora dalzelii, etc. \\
\hline Riparian & $\begin{array}{l}\text { Acacia nilotica, Ficus racemosa, Syzyzium cumini, Pongamia pinnata, Syzygium zeylanicum, } \\
\text { Ficus arnottiana, Homonoia riparia along with other terrestrial species like Bombax ceiba, } \\
\text { Lannea coromandellica, Xantolis tomentosa; Cyperaceae members and grasses like Saccharum } \\
\text { spontaneaum; herbs and shrubs like Ludwigia octovalvis, Phyllanthus reticulatus, Crinum } \\
\text { viviparum, etc. }\end{array}$ \\
\hline Plantation & $\begin{array}{l}\text { Tectona grandis associated with Terminalia elliptica, Bombax ceiba, Lannea coromandellica, } \\
\text { Madhuca latifolia, Grewia tilifolia. } \\
\text { Teak (Sag) plantation is also dominated by weedy undergrowth of Lantana camara with } \\
\text { other shrubby vegetation like Carrisa caranda, Woodfordia fruticosa, Gymnosporia senegalensis, } \\
\text { Jasminam malabaricum, etc. }\end{array}$ \\
\hline
\end{tabular}


- The species diversity is also high in case of scrub vegetation class. (Please see vegetation composition)

- Among Open land areas, rocky plateaus have typical vegetation in Monsoon season. Rocky plateaus are not level lands. By removing boulders of rocks, depressions are created on the plateau. We have seen paddy fields on such depressions.

- Inspite of heavy rainfall, we came across Euphorbia sp (Nivdung) associated with Artemisia nilagirica (Dhordavana), Woodfordia fruticosa, etc. indicating seasonally dry conditions. These conditions exist due to steep slopes which cannot hold soil and moisture.

- On the crest-line near Ahupe, the forest is bordered by Strobilanthes callosa (Karvi) vegetation. It is also found in patches on steep slopes.

- Plantation mainly consists of teak and few nonindigenous species like Gliricidia, Subabhul, planted on a fairly large area in the Dimbhe catchment.

\section{Discussion}

\section{Catchment Restoration Potential and Recommendations}

This study defines Restoration Potential of a dam catchment as the total area of land in the catchment underthe four main natural vegetation classes (Mature Forest, Dense Shrubbery, Scrub, Open land) and plantation. These classes can benefit from protection and restoration and lead to an improvement in nature's services and biodiversity. (Urbanska, 1997)

The overall region can be seen as a mosaic of habitats. Finding restoration potential in a specific part of it requires us to evaluate forest patches, corridors that connect patches, and matrices, which are arrays of various land uses and habitats around a forest patch, dotted with vegetation (Forman et. al. 1996). The ecological quality of the matrix (and it's variation over seasons) are important when restoring overall ecological health of a fragmented landscape (Jules et. al. 2003).

The central theme of our restoration recommendations is to protect good forest patches, restore degraded patches, connect patches using new or existing corridors where possible, and protect matrices (as they provide nature's services to surrounding forest patches).

\section{Pavana: Restoration Potential and Recommendations}

Restoration potential of the Pavana catchment is 68.96 sq. $\mathrm{km}$. Please refer to the Figure 5 when reviewing the recommendations below.
1. In the high and middle rainfall zone, we observed a lot of scrub. Ideally, there should be good forest cover, considering the rainfall in this area. Hence the large extent of scrub land here is unacceptable and indicates a high degree of degradation. We recommend this area (patches of scrub) as a top contender for restoration.

2. A lot of modern development including polyhouses is observed in the midst of mature forest. Such development and roads leading to them can cause further forest erosion, introduction of waste in natural ecosystems, and long term impact on nature's services. Such projects should not be allowed in mature forest areasin future. For already existing projects, the owners should be involved in landscape level restoration programs. The local councils and state government should consider restrictions on further development in/near mature forest.

3. In-stream agriculture is relatively high. It should be discouraged or sustainable alternatives should be provided.

4. Towards the North-West of the dam catchment, in the land-area between the villages Atvan, Ghusalkhamb, Morgiri and Jambhulne, there are large patches of mature forest fragmented by relatively small patches of modern development and agriculture. If a trade-land programcan be devised so that agriculture is shifted to other open areas, then the mature forest cover in this area can be increased. Successful examples of relocation of villages include Dhain (2004-05) and

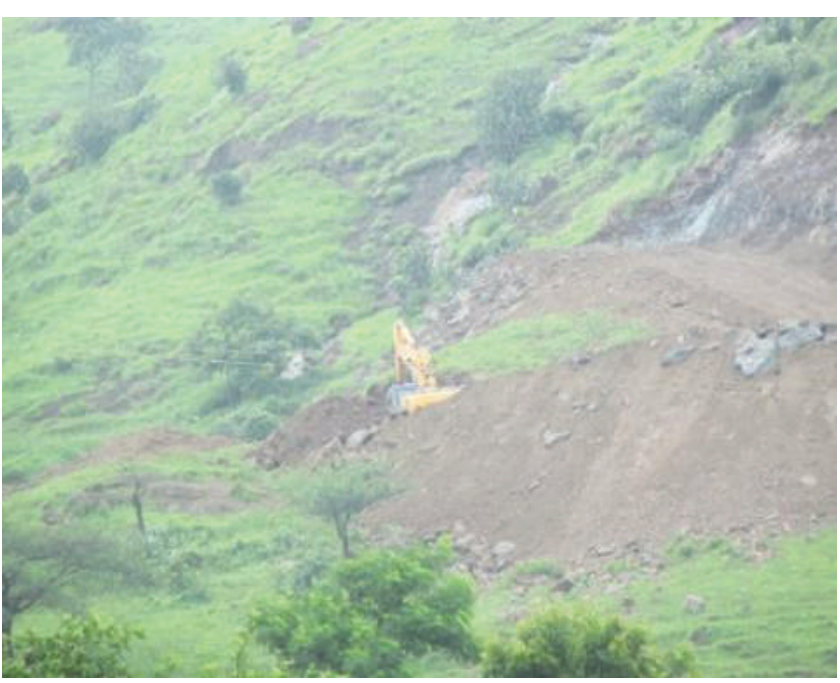

Figure 10: Road construction on hills in Chaskaman catchment 
Table 6 : Dimbhe Catchment: Area Statement as per Vegetation and Land Use

\begin{tabular}{|l|l|l|}
\hline Vegetation and Land use class & $\begin{array}{l}\text { Area under each Class } \\
\text { (sq. } \mathbf{~ k m ) ( ~ ( \% )}\end{array}$ & $\begin{array}{l}\text { Percentage Area w.r.t. } \\
\text { Total Catchment Area (\%) }\end{array}$ \\
\hline Mature Forest & 36.879 & 13.29 \\
\hline Dense Shrubbery & 41.408 & 14.92 \\
\hline Scrub & 45.325 & 16.33 \\
\hline Open & 53.817 & 19.39 \\
\hline Karvi & 1.245 & 0.44 \\
\hline Riparian Habitat & 1.664 & 0.59 \\
\hline Islands & 0.000 & 0 \\
\hline Waterbody & 15.831 & 5.70 \\
\hline Agriculture/ Horticulture & 74.436 & 26.83 \\
\hline In-Stream Agriculture & 3.525 & 1.27 \\
\hline Plantation & 0.569 & 0.20 \\
\hline Village Settlement & 1.698 & 0.61 \\
\hline Modern Development & 0.074 & 0.02 \\
\hline Road & 0.918 & 0.33 \\
\hline Quarry & 0.044 & 0.01 \\
\hline Total & $\mathbf{2 7 7 . 4 3}$ & $\mathbf{1 0 0}$ \\
\hline
\end{tabular}

Bori (2009-10) by NTCA/Project Tiger in the Satpura National Park as well as relocation of seven villages in the Melghat Tiger Reserve (2012-15). Similarly, owners of the land where modern development exists can be integrated in the restoration program. With proper protection, the patches of scrub and dense shrubbery adjacent to mature forest would automatically upgrade so as to form a continuous, large stretch of mature forest.

5. Similar condition is observed to the west of Shilimb, where there are large stretches of dense shrubbery in the midst of mature forest. Similar program to increase the extent of mature forest should be considered here.

\section{Chaskaman: Restoration Potential and Recommendations}

Restoration potential of the Chaskaman catchment is $185.45 \mathrm{sq}$. km. Please refer to Figure 9 when reviewing the recommendations below.

1. In the high rainfall zone, towards the west, near crest-line of Western Ghats, village settlements are few. Mature forest areas are surrounded by dense shrubbery area. With simply more protection mainly from human interference, these areas can be restored to a continuous stretch of mature forest. Some of the area within this zone belongs to forest department and may be effectively protected by preventing grazing and agriculture.

2. In the mid rainfall area of the catchment, dense shrubbery is present to the north of the reservoir. However, it is absent to the south of the reservoir. Logically, with same rainfall, even this area should support dense shrubbery vegetation. To make this possible, restoration programs should be devised including trading of land. The land owners can be given a substitute land in open areas identified in this study to practice agriculture.

3. There are a lot of open areas in the midst of dense shrubbery. In these areas, restoration should be practiced since it can evolve to the next stage in progression, i.e. mature forest.

4. The history and present trends in land ownership 
Table 7 : Dimbhe Catchment: Vegetation Composition and species composition

\begin{tabular}{|c|c|}
\hline $\begin{array}{l}\text { Vegetation class } \\
\text { Mature forest }\end{array}$ & $\begin{array}{l}\text { Species Composition } \\
\text { Semi-evergreen : Memecylon-Actinodaphne-Olea community is associated with } \\
\text { Mangifera indica, Xantolis tomentosa, Lepisanthes tetraphylla, Heterophragma } \\
\text { quadriloculare, Diospyros silvatica, Atalantia racemosa, Cryptocarya wightiana, Symplocos } \\
\text { racemosa, Mallotus phillipensis, Murraya koenigii, Bridelia retusa with shruby under } \\
\text { growth of Ixora brachiata, Mallotus stenanthus, Mallotus aureopunctatus, Gymnosporia } \\
\text { rothiana, Pavetta crassicaulis, Raulvaolfia verticillata and climber likes Rubia cordifolia, } \\
\text { Oxyceros rugulosus, Eleagnus conferta, Ancistrocladus heyneanus, Ventilago } \\
\text { bombaiensis, etc. }\end{array}$ \\
\hline & $\begin{array}{l}\text { Moist Deciduous forest: Mangifera indica-Syziygium cuminii-Terminalia elliptica with } \\
\text { Careya arborea, Dalbergia spp.-Bombax ceiba, Erythrina stricta, Ficus racemosa, } \\
\text { Lagerstromia parviflora, Xanthoxylum rhetsa, Terminalia chebula, etc. are associated with } \\
\text { shrubs and climbers like Carrisa congesta, Pavetta sp., Dioscorea bulbifera, } \\
\text { Paracalyx scariosus, Teramnus labialis, Tylophora dalzeli, Smilax ovalifolia, etc. }\end{array}$ \\
\hline Dense shrubbery & $\begin{array}{l}\text { Strobilanthes callosa, Woodfordia fruticosa, Carrisa congesta, Pavetta sp., Gnidia glauca, } \\
\text { Thespecia lampas, Grewia serrulata, Casearia graveolens, Holarrhena pubescens and trees } \\
\text { like Meyna laxiflora, Catunaregum spinosa, Terminalia elliptica, Bridelia retusa, } \\
\text { Flacourtia latifolia, Bombax ceiba, Syzygium cuminii, Ficus hispida, Emblica officinalis, } \\
\text { Wrightia tinctoria, Acacia ferruginea, Tectona grandis }\end{array}$ \\
\hline Scrub & $\begin{array}{l}\text { Acacia nilotica, Azadiracta indica, Fluggea leucopyrus, Calotropis gigantea, Lantana camara, } \\
\text { Euphorbia sps., Woodfordia fruticosa, Gnidia gluca, Maytenu ssp., Bridelia retusa, } \\
\text { Memecylon umbellatum, Flacaurtia latifolia, Ziziphus mauritiana, etc. }\end{array}$ \\
\hline Open area & $\begin{array}{l}\text { Among Open land areas, rocky plateaus have typical vegetation in Monsoon season. } \\
\text { Herbaceous species like Utricularia, Eriocaulon, Smithia, Impatiens, Crotalaria, } \\
\text { Indigofera, Swertia minor, Nanothamnus sericeous, Cythocline lutea, Hygrophilla serpyllum, } \\
\text { Smithiapurpurea grow on these plateaus. } \\
\text { Orchids like Habenariagrandifloriformis, etc. are associated with grass community like } \\
\text { Heteropogon contortus, Themeda quadrivalis, Apluda mutica, Andropogon sp. and shrubby } \\
\text { clusters of Carrisa congesta, Gnidia gluaca, Meyna laxiflora, etc. These grow on rocky } \\
\text { plateaus occupying their own niche. }\end{array}$ \\
\hline Karvi & $\begin{array}{l}\text { On the crest-line near Ahupe, the forest is bordered by Strobilanthes callosa (Karvi) } \\
\text { vegetation. It is also found in patches on steep slopes. }\end{array}$ \\
\hline Riparian & $\begin{array}{l}\text { Acacia nilotica, Ficus racemosa, Syzyzium cumini, Pongamia pinnata, Syzygium } \\
\text { zeylanicum, Ficus arnottiana, Homonoia riparia Vitex nigundo, along with other terres } \\
\text { trial species like Bombax ceiba, Lannea coromandellica, Xantolis tomentosa and Cyperaceae } \\
\text { members; grasses like Saccharum spontaneaum with herbs and shrubs like Ludwigia } \\
\text { octovalvis, Phyllanthus reticulatus. }\end{array}$ \\
\hline Plantation & $\begin{array}{l}\text { Tectona grandis, Gliricidia sepium, Lysiloma latisiliquum, Acacia auriculiformis, Eucalyptus } \\
\text { globosus, etc. }\end{array}$ \\
\hline
\end{tabular}




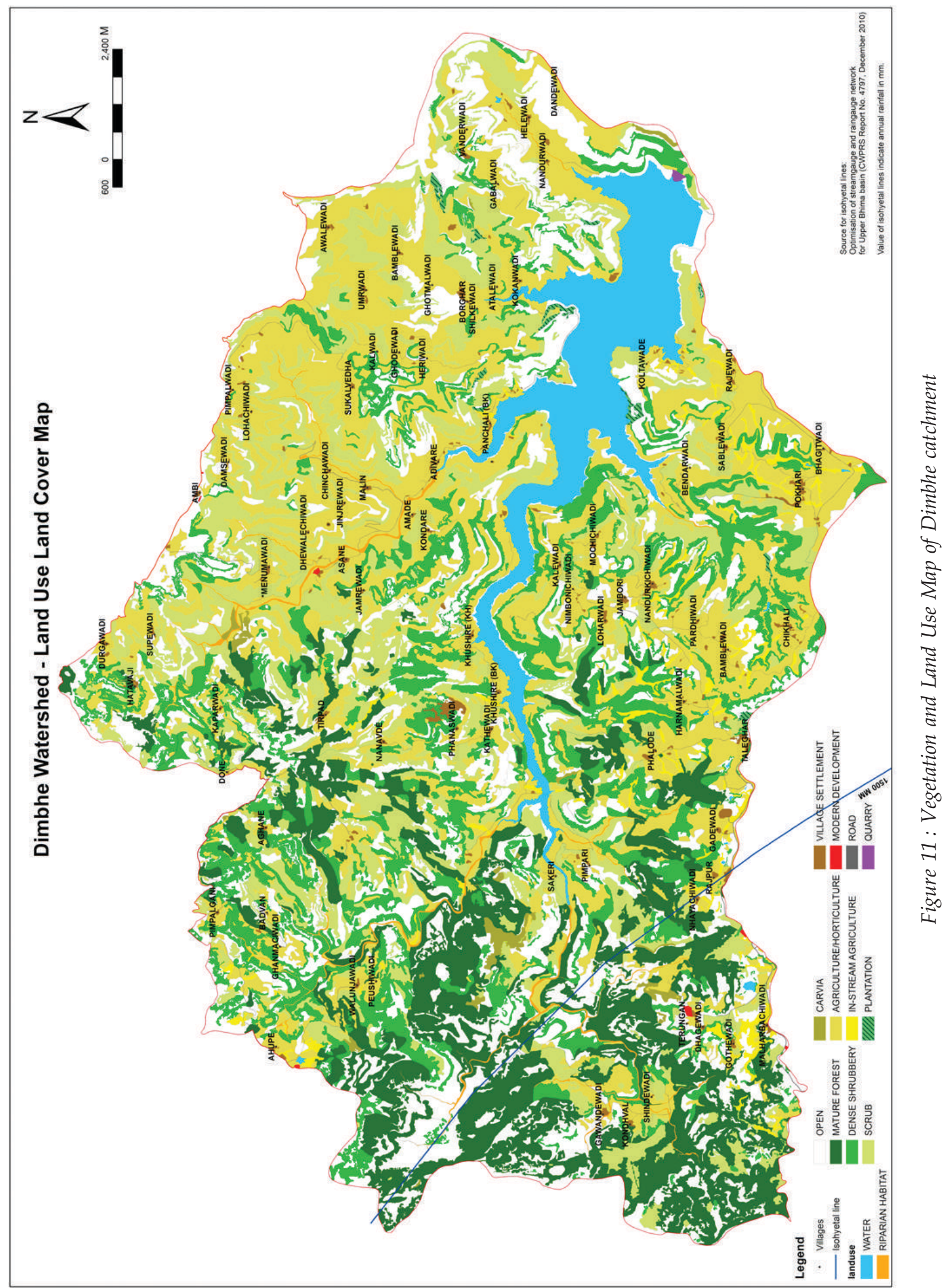


of tribals and other locals as well as their aspirations should be taken into account when planning restoration.

5. Regarding private owners asserting land rights by clearing mature forest on their own land, we suggest a land trade program be worked out with the owners. Owners can be offered subsidy or an alternative piece of land in open vegetation areas in the catchment.

6. Dense Shrubbery throughout the catchment should be provided protection.Protection can be provided by

a. Forest department if its within their reserved forest area

b. Land trade programs to bring more land under reserved forest, subject to socio-economic feasibility

c. By convincing private landowners for more protection and restoration. Suggested ideas could be

i. Private sanctuaries

ii. Landowner-conservator's collective (Pathak, 2015)

iii. Model Eco-sensitive Zones (Pathak, 2015)

\section{Dimbhe: Restoration Potential and Recommendations}

Restoration potential of the Dimbhe catchment is 177.99 sq. km. Please refer to the Figure 11 when reviewing the recommendations below.

1. To the west of the catchment, between Walunjwadi and Kondhwal, there are fragmented patches of mature forest and dense shrubbery. This area belongs to Bhimashankar Wildlife Sanctuary. A restoration program can be implemented by Forest Department to create continuous green cover.

2. There is a large extent of dense shrubbery throughout this catchment which should be provided protection. There is a need to educate the local community to know the benefits of protecting this vegentation type.

3. Continuity of mature forest and dense shrubbery areas should be a top priority. Both, currently are highly fragmented. Restoration programs should focus on creating corridors connecting these patches of dense shrubbery to increase available habitat for various kinds of biodiversity.

4. Agriculture in the hilly areas with steep slopes is difficult. Often it is subsistence agriculture, as is the case here, to the north-east of the catchment in the vicinity of villages Chinchawadi, Jinjrewadi, Shindewadi, Ghotmalwadi etc. A substi- tute land in the open areas could be offered to the owners and hilly areas could be provided complete protection for natural vegetation to grow.

5. Drainage density of this catchment is high indicating a large number of streams. However, compared to these number of streams, riparian vegetation is negligible. Creation of riparian zone along these streams will add ecological value to the catchment.

\section{Recommendations Applicable Across Catchments}

A few additional recommendations and ideas that could be applicable to any of the three catchments are given below :

1. At the policy level, absolute protection to the source regions of the rivers is recommended. Modern development should not be allowed in these areas.

2. Subsequent to the climate change talks in Paris in 2015, there is a renewed thrust on renewable energy in India. This may result in multi-fold increase in windmill installations in India over the next 1-2 decades. Over the past decade, we have already seen many new windmill projects coming up in the vicinity of Western Ghats. Chaskaman and Dimbhe catchments are likely to see more windmill activity, in addition to what is already seen. Wind-mills are generally preceded and followed by construction of roads. Accessibility brings about various secondary and tertiary changes in the landscape and can change land use rapidly.

Due to these concerns, we recommend that windmills should not be allowed near mature forest, dense shrubbery, forest corridors, biodiversityrich areas, or any other areas we have listed in this report as ideal for restoration. Windmill projects should also not be allowed to modify or change existing drainage and watershed structure in the catchment.

3. Considering the large number of village settlements in some of the catchments (e.g. Chaskaman or Dimbhe), Forest department, communities, and NGOs should work closely to create an equivalent of a sacred grove (devrai) in each village to increase green cover. This could be a novel program by the Social Forestry Dept or other parts of the Forest Department, in association with NGOs and local village councils. Each village could demarcate a patch of land for a Devrai and vouch not to touch it for many decadesto come. Being a devrai, even forest pro- 
duce or timber should not be taken from this area, or if taken, there should be high restrictions, enforced by the community. The location of this patch should be such that it adds to nature's services in the area e.g. pollination, water retention, soil conservation, erosion control, etc. This initiative could get plants of indigenous species from the forest department/social forestry department and ongoing inspection and consulting from NGOs. They should also get government grants and awards for improving the forest.

In the state of Maharashtra, the Jalayukta Shivar (farm pond) scheme was given top priority and rapid implementation by the government from 2014. A similar thrust could be put behind the "Sacred Grove in every village" scheme.

4. Karvi, especially on the steep slopes plays an important role in preventing soil erosion. Also at that gradient, nothing else than Karvi flourishes. The local communities extract Karvi for their livelihood. Exploitation of Karvi in such areas should be sustainably managed along with the community.

5. Communities in these catchments are dependent on local resources like fish. Small bunds across the streams and fish ladders can be introduced in the streams to increase fish yield. In a prior demonstration study done by Ecological Society in the Chaskaman dam catchment during 199798, it was observed that villagers caught fish during monsoon season, by utilizing a cloth as net across stream. It was observed that fish go up-hill for laying eggs. In this study, very low bunds were constructed in the catchment and the resulting habitat was useful to both fish and local community of fishermen.

\section{Restoration Prioritization across Catchments : A framework}

The study also attempts to address the possibility that a funding agency, an NGO, or a government department may be faced with the decision of selecting a given dam catchment for restoration from among multiple such candidates. This could happen due to budget and time constraints, interest in relative restoration potential, and so on.

The framework below tries to answer the above question, on an experimental basis.Itis based on our limited analysis and not on any focused or empirical studies. It is an intuitive framework based on our general experience with restoration in the Western Ghats.
Disclaimer : For selecting a given catchment among multiple such candidates for restoration, several aspects are pertinent. We only cover a subset of these below. Moreover, most of the scoring methods we provide below are simple and could be refined. Further analysis and enhancement of this framework is needed.

\section{Extent of vegetation cover}

For our purposes, this is the percentageof land in the catchment under the four natural vegetation classes: mature forest, dense shrubbery, scrub, and open land. The higher the extent, the more the potential for protecting vegetation and improving natural forest. On the other hand, it could be argued that the lower this number, the more the need for restoration, since this area is eroded and is in need of restoration. While both these arguments are true, we recommend the "higher" extent as a driver for determining potential, simply because the more the vegetation, more the nature's services that can be counted upon from this area.

A simple scoring scheme for this parameter could be as : $1(<25 \%), 2(25-50 \%), 3(50-75 \%), 4(75-100 \%)$. Extent of vegetation cover and scores for our three dam catchments are given in Table 8 .

\section{Overall amount of fragmentation of natural vegetation}

Fragmentation is the effect of land use changes due to human intervention of all types, gradual natural processes including land erosion, climatic conditions over the years, or calamities (e.g. landslides or diseases on plants). The more the fragmentation of vegetation, the longer the time, and more the effort and costs that will be needed to restore a landscape.

Fragmentation could be measured using sophisticated GIS analysis techniques (e.g. statistical analysis of vegetation class polygons in an average unit area of a landscape), however we could not attempt this during the course ofthis project.

For now, we have a simple scoring scheme, based on a subjective assessment of the LULC maps, as below: Fragmentation score for our three dam catchments are given in Table 8.

\section{Conduciveness of natural conditions}

This is an important dimension for restoration and we can think of sub-dimensions as below.

\section{a. Rainfall}

The more the rainfall, more is the water availability 
Table 8 : Comparative Scoring across Dam Catchments for Restoration Potential

\begin{tabular}{|l|c|c|c|c|c|c|c|c|c|}
\hline $\begin{array}{l}\text { Catchment } \\
\text { Scores } \\
\text { and Values }\end{array}$ & $\begin{array}{c}\text { Extent of } \\
\text { Vegeta- } \\
\text { tion } \\
\text { Cover }\end{array}$ & $\begin{array}{c}\text { Extent of } \\
\text { Fragmen- } \\
\text { tation }\end{array}$ & Rainfall & $\begin{array}{c}\text { Drainage } \\
\text { Density } \\
\text { (Compu- } \\
\text { ted in } \\
\text { bracket) }\end{array}$ & $\begin{array}{c}\text { Soil } \\
\text { Quality }\end{array}$ & $\begin{array}{c}\text { Shape of } \\
\text { catchment }\end{array}$ & $\begin{array}{c}\text { Extent of } \\
\text { human } \\
\text { land use }\end{array}$ & $\begin{array}{c}\text { Vicinity } \\
\text { to cities }\end{array}$ & $\begin{array}{c}\text { Total } \\
\text { Score }\end{array}$ \\
\hline Pavana & $\begin{array}{c}3 \\
(65 \%)\end{array}$ & $\begin{array}{c}3 \\
\text { Low }\end{array}$ & 3 & $\begin{array}{c}3 \\
(2.9)\end{array}$ & 2 & $\begin{array}{c}1 \\
\text { Circular }\end{array}$ & $\begin{array}{c}4 \\
(16 \%)\end{array}$ & 1 & 20 \\
\hline Chaskaman & $\begin{array}{c}3 \\
(60 \%)\end{array}$ & 2 & 1 & $\begin{array}{c}3 \\
\text { medium }\end{array}$ & 3 & $\begin{array}{c}2 \\
\text { Elongated }\end{array}$ & $\begin{array}{c}3 \\
(39 \%)\end{array}$ & 2 & 19 \\
\hline Dimbhe & $\begin{array}{c}3 \\
(62 \%)\end{array}$ & $\begin{array}{c}1 \\
\text { High }\end{array}$ & 2 & $\begin{array}{c}3 \\
(2.9)\end{array}$ & 2 & $\begin{array}{c}2 \\
\text { Elongated }\end{array}$ & $\begin{array}{c}3 \\
(29 \%)\end{array}$ & 3 & 19 \\
\hline
\end{tabular}

in a catchment on an annual basis. Nature's response to higher rainfall is faster growth of forests. The scoring for scale for rainfall should not be absolute, but should be determined in a relative way, among the candidate catchments. In our case, all three catchments are in the Western Ghats, but Pavana gets relatively more rainfall while Dimbhe and Chaskaman get relative less. The relative scoring is provided in Table 8 .

\section{b. Drainage Density}

The higher the drainage density, the more the length of drainage paths in a unit geographic area. Hence higher drainage density will mean relatively more water availability, making a catchment more conducive for restoration. More drainage density also results in higher habitat diversity and supports diverse platforms. This too should be a relative measure among the available candidates with some kind of indexation applied.

Since the drainage densities of the three catchments are close to each other, we assign the same and arbitrary score of 3 to all. If any of them was to have a significantly lower drainage density, say $<1$ or between 1-2, a lower score like 1 or 2 could be assigned.

\section{c. Soil Quality}

Richer the soil quality in a given landscape, higher will be chances of success of restoration since less effort will need to be spent in enriching the soil. Soil Quality measures could be elaborate and will need detailed sampling and analysis methodologies. Also it may not be entirely correct or easy to assign a single soil quality measure across the landscape. Rather, a basket of soil measures may need to be worked out. In the absence of all this, we have assigned subjective scores to the soil quality in the three catchments based on our general observations.

\section{d. Shape of catchment}

The more elongated a catchment, the higher the probability that multiple, varying "rainfall instances" will happen across the length of the catchment. This means more rain will be retained and drainage will be gradual. On the other hand, the more circular a catchment, the faster will be runoffout of the catchment. Thus the shape of the catchment has an impact on the extent of moisture retention, which in turn affects restoration potential. Scoring across catchments on this parameter will be relative. A rigorous quantitative model for shapes can be done using measurement of long and short axes, further spatial analysis, etc. For now, simple scores for our three catchments, based on our assessment of their shape is provided in Table 8.

\section{Conduciveness of human conditions and interference}

Restoration programs cannot be successful without the involvement of stakeholders. It may be important to develop a variety of measures to express how conducive the general human conditions in a catchment are, for restoration. Below are two sample measures.

a. Degree of human land use

We have simplified this measure to take the sum total of percent land under all human use. This could be fine-tuned further to consider the varying impact each of them may have on restoration efforts. E.g. Roads bisect forests and affect habitat development, 
while in-stream agriculture modifies drainage in the system. Grazing and fire have a direct impact on soil. Village settlements and modern dwellings may be sources of waste that choke up natural ecosystem flows. All these impact ecosystem health and hence restoration success.

For now, we will simply add up all human land use and assign a score as $4(<25 \%), 3(25-50 \%), 2(50-75 \%)$ and $1(75-100 \%)$. Extent of human land use and scores for our three dam catchments are given in Table 8

\section{b. Vicinity to cities}

Particularly in a densely populated, developing country like India, the more the vicinity of a forest to a major metro area, higher the chances that human land use in future may suffer from "urban effects", including urbanites buying land, developers building farm house schemes, large companies choosing these areas for townships and private hill stations, tourism, and so on.

Thus simply being near a city can affect the potential for restoration. The farther an area from a city, relatively less will be the urban interference. This could also be modelled quantitatively though actual distances and road connectivity to nearby metros. For now, we observe that Pavana is very near to Mumbai, Pune and Lonavala, while Dimbhe and Chaskaman have only Pune as a nearby city, but not as close as in case of Pavana. The scoring is given in Table 8 .

\section{Composite Scores of the Three Catchments}

After developing such basic measures, we could consider arriving at a composite score to provide a more definitive answer as to how to prioritize across catchments based on their restoration potential. For this, various weighted average or other such formulae could be considered. For now, we will do a simple addition of the above scores.

Thus, in this case, the simple model developed above does not provide a distinctly attractive candidate for restoration. Rather all three catchments score close to each other and have similar restoration potential.

In such a case, a decision could be made based on the total sq. km. of restoration potential in the catchment. In our case, the highest potential is with the Chaskaman catchment, of $185.45 \mathrm{sq}$. km.

In conclusion, our study of vegetation cover, land use and ecological status of the Pavana, Chaskaman, and Dimbhe catchments points to the significant restoration potential of such regions and how restoration can contribute to the larger objective of conserving the
Western Ghats biodiversity hotspot. A landscape ecological approach, with restoration potential as a basis for discussion, can help develop a constructive dialog between all the stakeholders i.e. government departments, local communities, ecological and socio-economic experts and NGOs. We hope this study and similar such studies provide useful data for such dialogs and prioritization of restoration.

\section{Acknowledgements}

We are grateful to Global Forest Watch (GFW) and World Resources Institute (WRI) for their support of this work under the Small Grants Program. We would like to thank Maharashtra State Forest Department officers for their interest and support of this project.

\section{Note}

The online supplementary data for this article is available at following link or by writing to the lead author. https://bit.ly/2BhP5uc

\section{References}

Ecological Society (2014). Report of Ecological Survey undertaken in Panshet Catchment and Bhimashankar Wildlife Sanctuary.

Gole, P. (1985). An enquiry into the status of animal and plant life in critical areas of Western Ghats in order to evolve a plan to conserve their biological diversity, Vol. I and II, Ecological Society.

Gole, P. (1990). Restoration of Biological Diversity: The final technical report, 1989-90.

Gole, P. (2007). Ecological and Social Dynamics of an Irrigated Reservoir, in The Restoration of Nature. Ecological Society, Pune.

Water Resources Information System of India (last retrieved Sept 2018). Dams in Krishna basin. Retrieved from http://india-wris.nrsc.gov.in/ wrpinfo/index.php?title=Dams in Krishna Basin

Central Water and Power Research Station CWPRS (2010) : Report No. : 4797 - Optimisation of stream gauge and rain gauge network for upper Bhima basin.

Gov. of Maharashtra, Forest Department (2011) Working Plan for the forests of Pune Forest Division: 2012-13 to 2021-22, Vol. I and II

Gov. of Maharashtra, Forest Department (2006) Working Plan for the forests of Junnar Forest Division: (2004-05 to 2013-14)

Gov. of Maharashtra, Water Resources Department, (n.d.). Upper Bhima Sub-Basin Draft Report

Urbansaka, K. M., Webb,N. R., and Edwards, P. J. (1997). Restoration Ecology and Sustainable Devel- 
opment. Cambridge University Press.

Bradshaw A.D., and Chadwick M. J. (1980). The Restoration of Land. Blackwell Scientific.

Forman Richard T. T., Gillilan David M., and Dramstad Wenche E. (1996). Landscape Ecology Principles in Landscape Architecture and Land-Use Planning. Island Press.
Jules, Erik S. and Shahani, Priya (2003). A broader ecological context to habitat fragmentation: Why matrix habitat is more important than we thought. Journal of Vegetation Science 14: 459-464.

Pathak, Y. (2015). A Report on Socio-Economic Status in Villages of the Panshet Dam Catchment Region. Journal of Ecological Society, v.28, pp. 79-90. 